\title{
複数台のレスキューロボットを遠隔操縦するための GUI と被災地用 マルチホップ無線ネットワーク機器を自動配置するシステムの評価 \\ Evaluation of plural rescue robots remote control GUI and multi hop wireless network device distributing system
}

$\begin{array}{llllll}\bigcirc & \text { 西橋 哲郎 (岡山大) } & \text { 学 } & \text { 松下 史弥 (岡山大) } & \text { 学 } & \text { 村上 典彦 (岡山大) } \\ \text { 正 } & \text { 亀川 哲志 (岡山大) } & \text { 正 } & \text { 五福 明夫 (岡山大) } & & \text { 佐藤 徳孝 (電通大) } \\ & \text { 大村 誠司 (トピ一工業) } & & \text { 宇夫 陽次朗 (IIJ) } & \text { 正 } & \text { 松野 文俊 (電通大) }\end{array}$

Tetsuro NISHIHASHI, Fumiya MATSUSHITA, Norihiko MURAKAMI,

Tetsushi KAMEGAWA, Akio GOFUKU, Okayama Univ.

Noritaka SATO, Fumitoshi MATSUNO, UEC

Seiji OOMURA, Topy Industries Ltd. ,Youjiro UO, Internet Initiative Japan Inc.

\begin{abstract}
We developed new rescue robot system that plural rescue robots are remotely controlled by one operator. In this system, a pioneer type robot put multi hop wireless network devices to extend area that surveyor type robots are able to search victims and surroundings in a damaged building. In this paper, evaluation of GUI interface to operate plural rescue robots and distributing system of wireless network device are shown.
\end{abstract}

Key Words: rescue robot, GUI for plural robots remote control, putting of multi hop wireless network device

\section{1.はじめに}

近年, 大地震等の自然災害や事故等の人為災害で倒壊し た建物の内部を探索して要救助者を見つけ出すレスキュー ロボットの研究開発が推進されている。レスキューロボッ 卜を用いる事により，二次災害による被害の防止や人が入 れない場所での探索が可能となると期待されている。し かし従来のレスキューロボットは, 1 人の操縦者が 1 台の ロボットを操縦するというシステムが主流であった。そ こで，我々はインフラの整備されていない被災建物内に おいて，さらに効率の良い探索を行うために複数台のレ スキューロボットを運用するためのレスキューロボット システムを開発してきた1)213)。この中には，複数台のロ ボットを遠隔操縦するための GUIや，多数のロボットを 広範囲にわたり遠隔操縦するための「被災地用マルチホッ プ無線ネットワーク機器」(以下，Robohoc デバイスとす る)が含まれている。本稿では，上記の GUIの操作性，柔 軟性，汎用性を向上させる事とRobohocデバイスを格納 するケースを設計，製作してロボットがこれを設置する システムを構築する事を目的としてそれぞれ試作，改良 を行い,これらを評価した結果を示す。

\section{2. システムの構成}

$2 \cdot 1$ 高機能兄弟型移動プラットフォーム

Fig. 1 に本研究で使用したレスキューロボットを示す. Fig. 1 中の左側のロボット (以下，兄ロボットとする)は

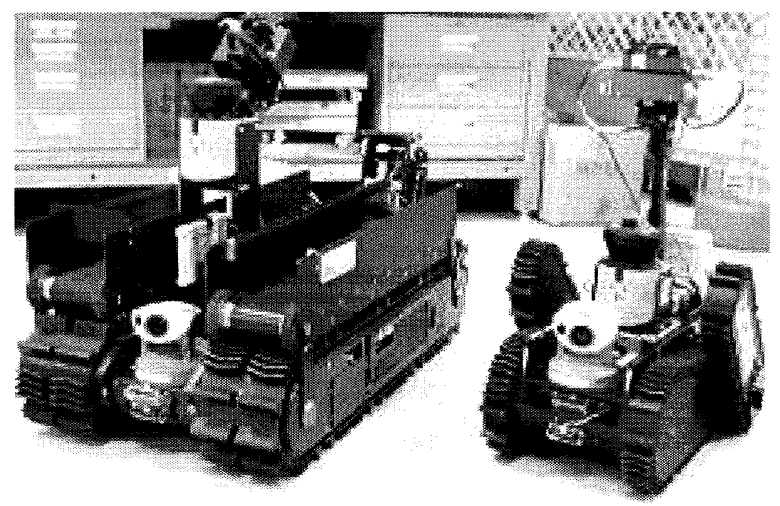

Fig.1 Developed mobile robot platforms (left:pioneer type,right:surveyor type)

ロボット群の中に 1 台存在しており，主に手動で遠隔操縦 され，自身に搭載された Robohoc デバイスを設置してい く，右側のロボット(以下，弟ロボットとする) はロボッ 卜群の中に複数台存在し，特定の探索アルゴリズムに基 づいて半自律的に要救助者の探索を行う想定となってい る，弟ロボットは必要に応じて手動で操作する事も可能 である.どちらのロボットも階段の昇降や不整地での走 行が可能である．兄ロボットと弟ロボットのハードウェ アのスペックは, 文献 1)を参照されたい. 


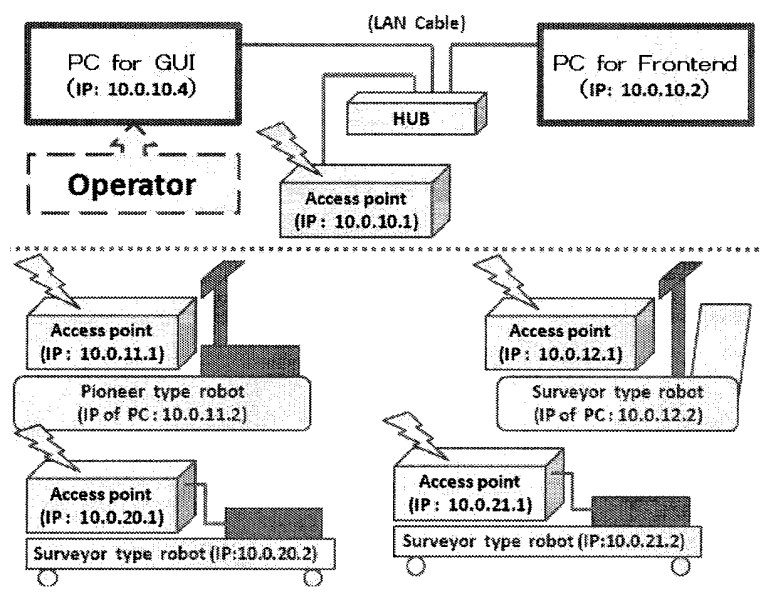

Fig.2 Composition of each elements and network

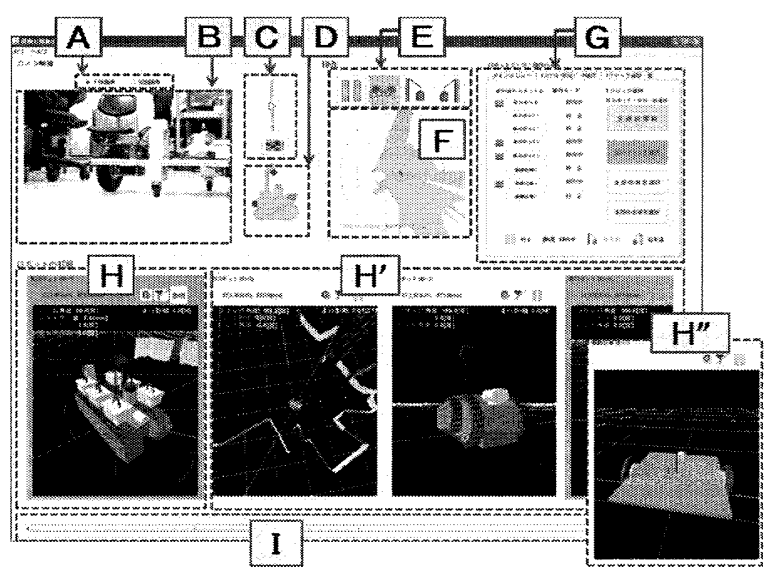

Fig.3 Display of the GUI

\section{$2 \cdot 2$ ネットワーク構成}

本研究で改良した GUI から複数台のロボットを無線で 遠隔操縦し，様々な実験を行うために Fig. 2 に示すネッ トワークを構成した，本稿の実験では Robohoc デバイス は使用していないが，Robohocデバイスを使用したマル チホップの環境でも同様に複数台のロボットの遠隔操縦が 実現されている，図中のフロントエンド用PCには，GUI 及びロボットから送信されるUDP プロトコルのデータ の整理を行うためのフロントエンドサーバが実装されて いる.

\section{3. 複数ロボット操縦用 GUI}

\section{$3 \cdot 1$ GUI の概要}

本研究で改良した複数ロボット操繸用 GUI Fig. 3 に 示し, 各要素の名称とその機能を以下に述べる.

・A：画像配信方法選択パネル：ロボットがカメラ映 像を 1 枚の画像として送信するか，1枚の画像を分 割したデータとして送信するかを選択する。

・B：カメラ映像パネル：ロボットから送られてきた
前浔び俯瞰視点カメラの映像を表示する.

- C : カメラクオリティ変更ボタン：ロボットから送 信されるカメラ映像の圧縮率とフレームレートを変 える，切替ボタンでどちらを変えるか選択し，スラ イダーバーで調節を行う。

・D：カメラ選択パネル：ロボットのどのカメラの映 像を送信するかを選択する。

・ $\mathrm{E}$ : 走行モード選択ボタン: 操縦者が選択したロボッ トに 4 種類の走行モードの指示を出す．各ボタンの 機能は左から順に「停止」「手動操作」「左手法」「右 手法」の指示を出す.

- F : LRF データ表示パネル：選択されたロボットの LRF のデータがロボットを中心に表示される．ま た，このパネル上をクリックする事により，指示し た方向にロボットが自律走行するモードになる。

- $\mathrm{G}$ : 複数ロボット操作・情報表示インターフェイス： 本研究において GUI を改良するにあたり実装した インターフェイス．3枚のタブパネルから構成され ており, 複数ロボットの走行モード表示や一括選択 が可能である。

・H：ロボットパネル：Hはロボットの状況 (操作モー ド・通信状沉・OpenGLによる 3D モデル)を表示 するパネルである。パネル上をクリックする事でロ ボットの選択または選択の解除が行える。選択され ている時はパネル回りが青色に変化し，選択された ロボットに GUI からのコマンドを送る事が出来る. $\mathrm{H}, \mathrm{H} ， \mathrm{H}^{\prime}$ はそれれぞれ兄ロボット用，弟ロボット用， 移動台車用 (本研究で新たに追加) であり，設定し たロボットの数だけパネルの增減が可能である.

・I：スクロールバー：ロボットパネルは画面右方向 に追加されていくため，画面外のロボットの状況を 知るためにはこのスクロールバーをドラッグしてロ ボットパネルを表示する。

\section{$3 \cdot 2$ GUI 操作量の評価実験}

構築した GUI の有効性を評価するために，一定のシナ リオを遂行する時の操作量に関する実験を行った，実験 では，7台のロボットが存在すると仮定（実際には兄・弟・ 移動台車 2 台の計 4 台が存在）して，まず兄ロボットを手 動で操作し，その後弟ロボットと移動台車に自律探索の 指示を出すという一連の操作を 5 名の被験者 (ロボットの 操縦がはじめての理系男子学生)に実施してもらった。 そ の際に GUI 画面上でマウスカーソルが移動した距離とク リックした回数を計測し, Fig. 3 の Gのインターフェイ スを追加した改良の前後でそれぞれの値を比較した．実 験によって得られた結果を Fig. 4 に示寸. Fig. 4 より, マウスカーソルの移動距離が改良前の GUI に比べ改良後 


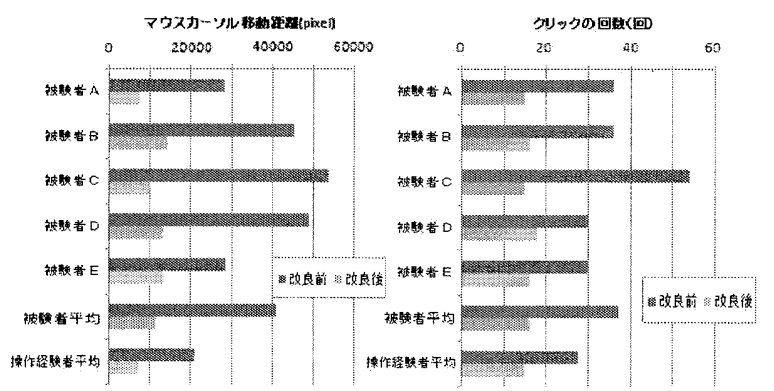

Fig.4 Moved distance of mouse cursor and number of times of mouse click

は平均で約 3 分の 1 に減少している.また，クリックの回 数も平均で改良前の約半分に抑えられた事が分かる。さ らにいずれの結果も，被験者間の值のばらつきが改良後 では小さくなっている，評価実験により，複数台のロボッ トを操作するための一括選択インターフェイスを追加す ることによって GUIが改良された結果, 操縦者の操作量 が減り，操作における負担が減ったことが確認できた。ま た，開発したGUIはロボットの数や種類が増えても柔 軟に対応でき，ある程度の汎用性があることを確認した。

\section{3 ロボットパネル内 3 次元 $\mathrm{CG}$ の構築と評価}

レスキューロボットを遠隔操縦するにあたり，ロボット に搭載された各種センサの状態やロボットの状態を Fig. 3 のHのロボットパネル内で視覚的に描画する事でロボッ 卜の遠隔操作性の向上を図っている。無線の帯域が保証 されない環境において，俯瞰カメラ映像以外の通信帯域 を压迫しないデータを用いて客観的なイメージを操作者 に提示することは，非常に重要である．Fig. 5 に 3 次元 $\mathrm{CG}$ モデルを示す。左側が兄ロボット，右側が弟ロボッ トの 3 次元 CG である.ロボットの 3 次元 $\mathrm{CG}$ モデルは OpenGL を用いて作成し，必要な部分以外を省略する事 で描画にかかる負担を極力減らしている，作成した 3 次 元 CG モデルでは，ロボットの姿勢描画，多目的ア一ム 等の可動部の動き，壁を描画する事による障害物までの 距離表示，速度に合わせたクローラの動き， クローラの 色を変える事によるロボット内部モードの表示等の機能 を搭載している。

\subsection{3 次元 $\mathrm{CG}$ の評価実験}

本研究ではこの 3 次元 CG の有効性を示すために, 3 次 元 CG モデルがある場合と無い場合について，被験者が 弟ロボットを遠隔操縦して迷路内の走行を行った結果を 比較した。被験者は理系学生 10 名とし， 3 次元 CG が無

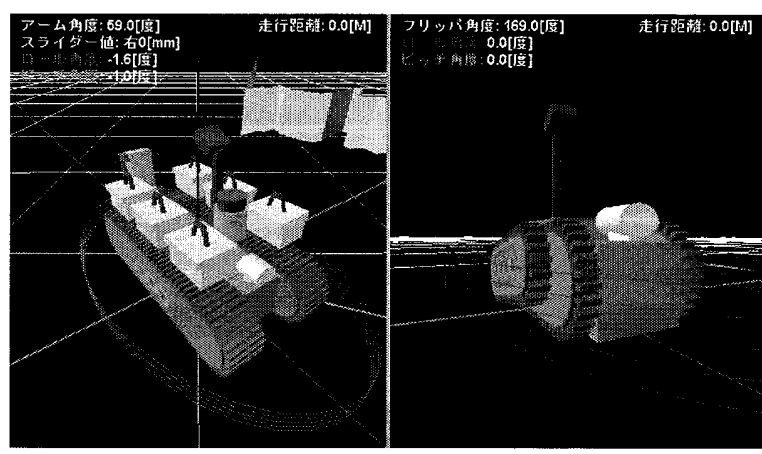

Fig.5 Three dimensional CG model

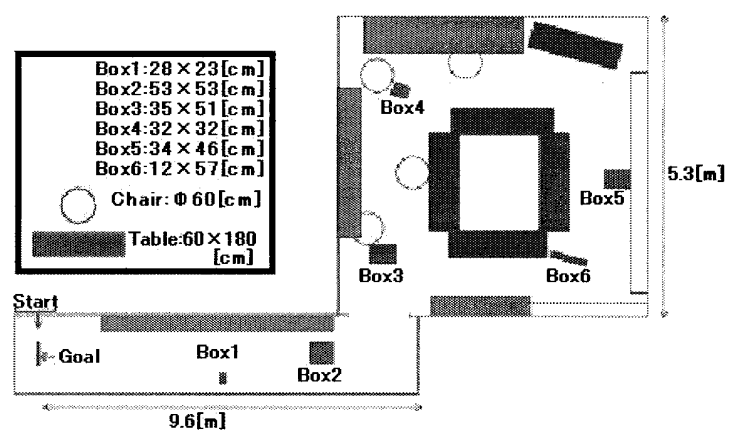

Fig.6 Course with obstacle

い場合の GUI はロボットの前方カメラ映像 (Fig. 3 のB) と 2 次元 $\operatorname{LRF}$ (Fig. 3 の F) の情報のみが提示される. 3 次元 CG 有りの場合はこれに加えて 3 次元 CG(Fig. 3 の H) を提示する. 評価の指標として, 迷路走行に要した時 間とロボットが障害物に衝突した回数を測定した。また, 前方力メラ映像, 2 次元 LRF 画面, 3 次元 CG モデルの 画面を見ていた割合についての主観的なアンケート調査 を行った.

Fig. 6 に迷路走行を行った環境を示す．実験を行った 結果，迷路走行に要した時間は 3 次元 CG の有無に有意 差がほとんど見られなかった。これは，3 次元 CGによ りロボット周辺の障害物の情報がはっきり分かり易い故 に被験者が慎重に操作したためと考えられる。障害物に 衝突した回数については 3 次元 CG が無い GUI で平均 2.8 回であったのに対し，3 次元 CGが有る GUI では平 均 1.4 回と半分になり, 3 次元 CG モデル画面の有る方が 有効であった. アンケート調査の結果では 3 次元 $\mathrm{CG}$ モ デルが有る GUI の場合, 3 次元 $\mathrm{CG}$ モデル画面を 5 割以 上, 2 次元 LRF 画面は 1 割未満しか見ていないという回 答が得られた。これら実験結果とアンケート結果から，3 次元 CG モデル画面は迷路走行中に俯瞰視点力メラと同 様に障害物との距離を把握出来る等の点で有効であると 考えられる。 


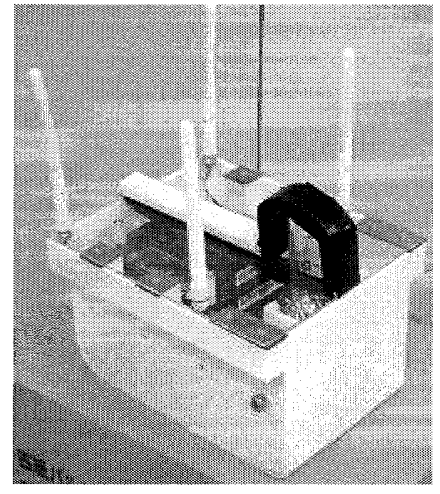

Fig.7 Overview of multi hop wireless network device

\section{Robohoc デバイスのケース設計と設置実} 験

\section{$4 \cdot 1$ ケースの設計と製作}

兄ロボットが運搬・設置するRobohoc デバイスのケー スの形状は见ロボットにより多く搭載出来るようにコン パクト，かつ軽量である事が望ましい，また，無線電波の フェージングを防ぐために空間ダイバーシティー法をと りいれ，アンテナ間の距離を波長分 $(125[\mathrm{~mm}])$ はなす設 計となっている，以上の事を考慮にいれ，3 次元 $\mathrm{CAD}$ で 外形を設計し， ABS 樹脂を素材として 3 次元プリンター で製作した Robohoc デバイスを Fig. 7 に示す．重量は 1055[g]，サイズは L:197 × W:150 × H:109[mm]である.

\section{2 自動設置システムの構築と有効性の検証}

作製したRobohoc デバイスは，ケースのフックに兄ロ ボットのアームを引っ掛け，兄ロボット上の積載スペー スから Robohoc デバイスを吊り下げて環境に設置する. この操作を遠隔操縦によって行う場合，兄ロボットに搭 載された俯㒈視点カメラの限られた視点・視野では設置 操作が困難である。 そこで無線中継器設置の一連の動作 を自動化し，その有効性を検証した。

被験者は 6 名の理系学生で、まず目視による手動設置 及びカメラ映像を見ながらの手動遠隔設置を行い，次に， 自動設置を実施してもらった，実験の結果を Fig. 8 に示 す，実験により，目視よりも遠隔での設置操作の方が難 しく，設置に多くの時間がかかる傾向がある事が分かる. 自動設置では目視，遠隔いずれの手動設置操作よりも短 時間で設置が完了する結果となった。

さらに，自動設置システムが環境の傾きに対してどれ ぐらい適用できるか実験したところ、ピッチ軸に-15〜 $25[\mathrm{deg}]$ ， ロール軸に-15 15[deg] までの範囲で適用でき る事を確認した。

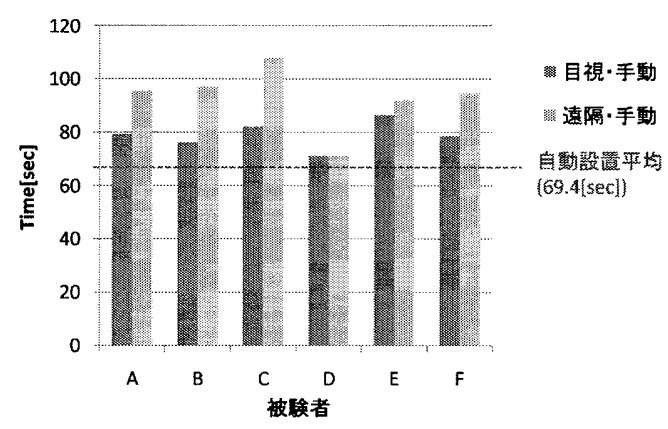

Fig.8 Comparison of setting times

\section{5. おわりに}

本研究では複数ロボット操縦用 GUI の改良と 3 次元 $\mathrm{CG}$ モデルの構築による操作性の向上，被災地用マルチ ホップ無線ネットワーク機器の製作と自動配置システム の構築を行い、それぞれの評価を行った実験結果を示し た．今後の課題は，より多くの種類，数のロボットを実 際に扱う事で実用的なシステムとして機能する事を実証 していくことである.

本研究は，独立行政法人新エネルギー・産業技術総合開 発機構（NEDO 技術開発機構）による「21 世紀ロボット チャレンジプログラム」の一環である「戦略的先端ロボッ 卜要素技術開発プロジェクト」により実施されました。

参考文献

1) Tetsushi Kamegawa, Kenta Saikai, Shinjirou Suzuki, Akio Gofuku, Seiji Oomura, Tsuyoshi Horikiri and Fumitoshi Matsuno:" Development of grouped rescue robot platforms for information collection in damaged buildings", Proceedings of SICE Annual Conference 2008, pp.1642-1647, 2008

2) Keiichi Shima, Yojiro Uo, Sho Fujita: " Auto configuration and management mechanism for the robotics self extensible WiFi network" , Proceedings of SICE Annual Conference 2008, pp.1648-1652, 2008

3) Noritaka Sato, Hisashi Mizumoto, Naoji Shiroma, Masahiko Inami, Fumitoshi Matsuno: "Touch-pen interface with local environment map for mobile robot navigation" , Proceedings of SICE Annual Conference 2008, pp.1632-1637, 2008 